\title{
Influence of Water Velocity and Vertically-Suspended Structures on Rainbow Trout Rearing Performance
}

\author{
Jill M. Voorhees, Nathan Huysman, Eric Krebs, Michael E. Barnes \\ South Dakota Game, Fish and Parks, McNenny State Fish Hatchery, Spearfish, South Dakota, USA \\ Email: jill.voorhees@state.sd.us
}

How to cite this paper: Voorhees, J.M., Huysman, N., Krebs, E. and Barnes, M.E. (2020) Influence of Water Velocity and Vertically-Suspended Structures on Rainbow Trout Rearing Performance. Open Journal of Animal Sciences, 10, 152-161. https://doi.org/10.4236/ojas.2020.101008

Received: November 14, 2019

Accepted: January 14, 2020

Published: January 17, 2020

Copyright $\odot 2020$ by author(s) and Scientific Research Publishing Inc. This work is licensed under the Creative Commons Attribution International License (CC BY 4.0).

http://creativecommons.org/licenses/by/4.0/

\begin{abstract}
This study evaluated the effects of two water velocities and three types of vertically-suspended environmental enrichment during the rearing of juvenile rainbow trout (Oncorhynchus mykiss, mean \pm SE, initial weight $4 \pm 1 \mathrm{~g}$ and total length $71 \pm 2 \mathrm{~mm}$ ) in 1.8 -m diameter circular tanks. The $2 \times 3$ experimental design used two velocities $\left(12.2 \mathrm{~cm} \cdot \mathrm{s}^{-1}\right.$ and $\left.30.5 \mathrm{~cm} \cdot \mathrm{s}^{-1}\right)$ and three structural treatments (aluminum rod array, plastic spheres, or no structure). After 116 days, the fish reared without any structure (control) at $30.5 \mathrm{~cm} \cdot \mathrm{s}^{-1}$ had significantly lower total tank weight, gain, percent gain, feed conversion ratio, and specific growth rate compared to the other treatments. Similarly, the fish reared with a velocity of $30.5 \mathrm{~cm} \cdot \mathrm{s}^{-1}$ without structure were significantly shorter and lighter than those in the other treatments. There was no significant difference in condition factor and relative fin lengths among the treatments. These results indicate that vertically-suspended environmental enrichment may be impacting fish rearing performance by altering tank water velocities.
\end{abstract}

\section{Keywords}

Environmental Enrichment, Exercise, Salmonid, Oncorhynchus mykiss

\section{Introduction}

Environmental enrichment in fish culture has been categorized into physical, sensory, dietary, social, or occupational enrichment [1] [2]. Physical enrichment involves alteration of the rearing environment to increase complexity, such as by adding structure. Sensory enrichment comprises of rearing techniques that stimulate the fish senses, while dietary enrichment relates to changes in food types or delivery. Social enrichment comprises anything affecting interaction with 
other fish or humans. Exercise is the primary type of occupational enrichment. Obviously, there can be overlap among these categories. For example, adding structures to rearing tanks (physical enrichment), may very well lead to sensory stimulation (sensory enrichment), interaction among the fish (social enrichment), and impact in-tank velocities (occupational enrichment) [3] [4].

Physical enrichment has been intensively studied. Investigators have placed a variety of structures in rearing tanks, including tree roots [2], woody debris [2] [5] [6] [7] [8], rocks and concrete blocks [8]-[14], and imitation aquatic plants [1] [2] [15]-[20]. However, most of these structural enhancements are incompatible with production-level hatchery rearing because they interfere with tank hydraulic self-cleaning, subsequently increasing labor demands and creating conditions favorable for disease outbreaks [14] [21] [22]. However, positive results have been reported using vertically suspended environmental enrichment that does not affect hydraulic self-cleaning [23]-[28].

Occupational enrichment frequently involves increasing water velocity to force fish to exercise. Exercise can lead to increased swimming abilities, rearing performance, and changes in behavior [29]-[34]. Previous studies have examined the effects of combining exercise with structural enrichment [29]-[34]. Kientz and Barnes [23] investigated vertically-suspended structure and exercise, but they only used one type of suspended structure (aluminum rods) and two velocities that were very similar over a relatively short period of time.

The objective of this study was to examine selected structural enrichments (vertically-suspended rods and vertically-suspended strings of spheres) at two different velocities during the long-term rearing of juvenile rainbow trout ( $O n$ corhynchus mykiss) in circular tanks.

\section{Methods}

The experiment was conducted at McNenny State Fish Hatchery, Spearfish, South Dakota, USA, using degassed and aerated well water at a constant temperature of $11^{\circ} \mathrm{C}$ (total hardness as $\mathrm{CaCO}_{3}, 360 \mathrm{mg} \cdot \mathrm{L}^{-1}$; alkalinity as $\mathrm{CaCO}_{3}, 210$ $\mathrm{mg} \cdot \mathrm{L}^{-1} ; \mathrm{pH}, 7.6$; total dissolved solids, $\left.390 \mathrm{mg} \cdot \mathrm{L}^{-1}\right)$. Approximately $1800(7.2$ $\mathrm{kg} \cdot \operatorname{tank}^{-1}$ ) juvenile Shasta strain rainbow trout (mean \pm SE; initial weight $4 \pm 1 \mathrm{~g}$ and total length $70.8 \pm 1.8 \mathrm{~mm} ; n=30)$ were placed into $24(n=4), 2000$-L circular tanks (1.8 m diameter $\times 0.6 \mathrm{~m}$ deep) on June 1,2017 . The study lasted 116 days.

A $2 \times 3$ factorial experimental design was used to evaluate the effects of two water velocities and three structures on rearing performance of rainbow trout. The two velocities use were $12.2 \mathrm{~cm} \cdot \mathrm{s}^{-1}$ and $30.5 \mathrm{~cm} \cdot \mathrm{s}^{-1}$. The lower velocity was the minimum velocity needed to maintain tank hydraulic self-cleaning. Velocities were recorded using a flow probe (FP111 Global Water Flow Probe, Global Water, College Station, Texas, USA). Readings were taken directly behind the incoming water spray bar about $0.3 \mathrm{~m}$ deep (half way in water column). Velocities were set at the beginning of the experiment and were kept constant 
throughout the study. The three different structural treatments used were no structure, aluminum rod array, and spherical array. The aluminum rod array consisted of fifteen aluminum rods $(0.95 \mathrm{~cm}$ diameter $\times 57.15 \mathrm{~cm}$ long) suspended through a corrugated plastic tank cover as described by Huysman et al. [35]. The spherical array consisted of five strings of seven hard-plastic spheres (6.35 cm diameter, PVC-free pit balls; Kiddy Up brand; Imperial Toy LLC, North Hill, California, USA) suspended through the corrugated plastic tanks cover as described by Kientz et al. [24]. A 32-g weight as added to the top and bottom of the strings to ensure the spheres remained submerged in the tanks. The spheres were solid-colored (red, green, blue, yellow, pink, or purple) and colors were randomly selected from a common pool to eliminate potential bias.

Fish were fed every $15 \mathrm{~min}$ during daylight hours with $1.5 \mathrm{~mm}$, extruded floating feed (Classic Trout, Skretting USA, Tooele, Utah, USA) using automatic feeders. Feeding rates were determined by the hatchery constant method [36], with an expected feed conversion ratio of 1.1 and a projected growth rate of 0.08 $\mathrm{cm} \cdot \mathrm{d}^{-1}$, which was a rate at or slightly above satiation. All tanks in this experiment received $86.7 \mathrm{~kg}$ of feed over the course of the experiment.

At the end of the experiment, total tank weights were acquired by weighing all fish in the tank to the nearest $0.1 \mathrm{~kg}$. In addition, five fish per tank were individually weighed to the nearest $0.1 \mathrm{~g}$, measured (total length) to the nearest $1.0 \mathrm{~mm}$, and fin lengths (dorsal, one pectoral, and one pelvic) were measured to the nearest $0.01 \mathrm{~mm}$ to obtain relative fin lengths [37]. The following equations were used:

$$
\begin{gathered}
\text { Gain }=\text { final weight }- \text { initial weight } \\
\text { Percent gain }(\%)=100 \times \text { gain } /(\text { initial weight }) \\
\text { Feed conversion ratio }(\mathrm{FCR})=(\text { food fed }) / \text { gain } \\
\text { Specific Growth Rate }(\mathrm{SGR}) \\
=100 \times(\ln (\text { end weight })-\ln (\text { start weight })) /(\text { number of days }) \\
\text { Condition Factor }(\mathrm{K})=10^{5} \times(\text { fish weight }) /(\text { fish length })^{3} \\
\text { Fin indices (relative fin length })=100 \times(\text { fin length }) /(\text { fish length })
\end{gathered}
$$

Data were analyzed using the SPSS (24.0) statistical program (IBM Corporation, Chicago, Illinois, USA), with significance predetermined at $p<0.05$. A two-way analysis of variance (ANOVA) was initially performed. If the two-way ANOVA indicated a significant interaction, then a one-way analysis of variance was conducted. Tukey HSD was used for all post hoc means separation testing.

\section{Results}

Significant interactions were observed between the velocity and structure treatments with total tank weight, gain, percent gain, feed conversion ratio, and specific growth rate. Subsequent analysis indicated that fish reared without any structure (control) at the higher velocity (exercise) had significantly lower total tank weight, gain, percent gain, feed conversion ratio, and specific growth rate compared to all the other treatments. Total tank gain was only $74.1 \pm 6.5 \mathrm{~kg}$ in 
the exercised control tanks, compared to over $100 \mathrm{~kg}$ in all the other treatment groups. Similarly, percent gain (Figure 1), feed conversion ratio (Figure 2), and specific growth rate (Figure 3 ) were also significantly different. Mortality was less than $0.5 \%$ during the experiment and was not significantly different among treatments.

There was also a significant interaction between the velocity and structure treatments with individual fish length and weight. Similar to the total tank data, the fish in the higher velocity exercised control tanks were significantly shorter and lighter than those in all of the other treatments (Table 1). There was no significant difference in condition factor and relative fin lengths among treatments. No negative impacts on circular tank hydraulic self-cleaning were observed in any of the tanks or treatments.

Table 1. Mean $( \pm S E)$ individual total lengths, weights, fin indices ${ }^{a}$ (dorsal, pectoral, and pelvic), and condition factors ${ }^{\mathrm{b}}(\mathrm{K})$ of rainbow trout reared in circular tanks containing different vertically-suspended structures with two water velocities. Means with different letters in same row differ significantly $(p<0.05, n=4)$.

\begin{tabular}{ccccccc}
\hline Velocity & \multicolumn{5}{c}{ High } & \multicolumn{3}{c}{ Low } \\
\hline Structure & None & Rods & Spheres & None & Rods & Spheres \\
\hline Length (mm) & $156 \pm 5 \mathrm{y}$ & $182 \pm 2 \mathrm{z}$ & $174 \pm 1 \mathrm{z}$ & $178 \pm 2 \mathrm{z}$ & $180 \pm 0 \mathrm{z}$ & $179 \pm 1 \mathrm{z}$ \\
Weight (g) & $42.0 \pm 3.4 \mathrm{y} 70.6 \pm 3.3 \mathrm{z}$ & $59.8 \pm 1.2 \mathrm{z} 63.9 \pm 3.7 \mathrm{z}$ & $66.3 \pm 3.7 \mathrm{z}$ & $65.0 \pm 5.1 \mathrm{z}$ \\
Dorsal index (\%) & $7.1 \pm 0.7$ & $7.1 \pm 0.8$ & $6.9 \pm 0.5$ & $6.2 \pm 0.6$ & $6.6 \pm 0.7$ & $7.1 \pm 1.0$ \\
Pectoral index (\%) & $9.0 \pm 0.6$ & $8.3 \pm 0.6$ & $8.3 \pm 0.5$ & $8.4 \pm 0.6$ & $7.7 \pm 0.4$ & $8.7 \pm 0.6$ \\
Pelvic index (\%) & $7.2 \pm 0.6$ & $6.5 \pm 0.5$ & $6.7 \pm 0.2$ & $6.7 \pm 0.5$ & $6.5 \pm 0.3$ & $6.9 \pm 0.4$ \\
K & $1.10 \pm 0.03$ & $1.17 \pm 0.02$ & $1.13 \pm 0.02$ & $1.12 \pm 0.06$ & $1.12 \pm 0.08$ & $1.16 \pm 0.06$ \\
\hline
\end{tabular}

a) Fin indices $=100 \times($ fin length/fish length $)$ b $) \mathrm{K}=10^{5} \times\left(\right.$ fish weight $\left./(\text { fish length })^{3}\right)$.

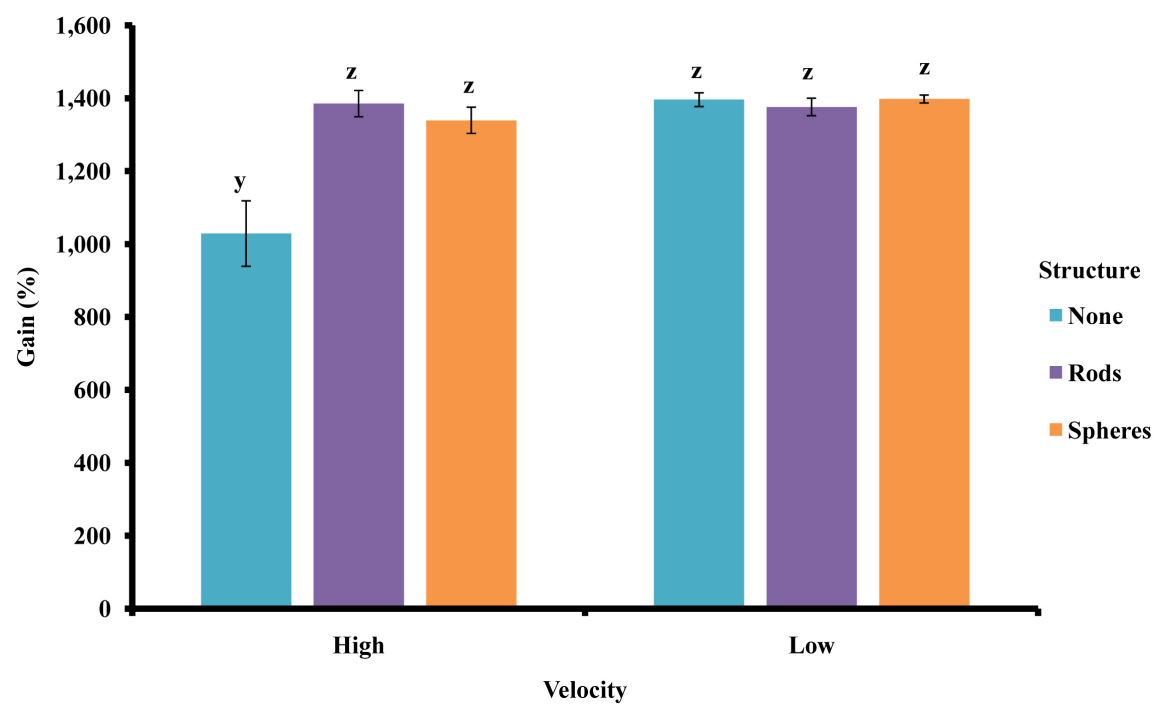

Figure 1. Mean $( \pm \mathrm{SE})$ percent gain of juvenile rainbow trout reared at two different velocities and with three different types of structures for 116 days. Means with different letters are significantly different $(p<0.05, n=4)$. 


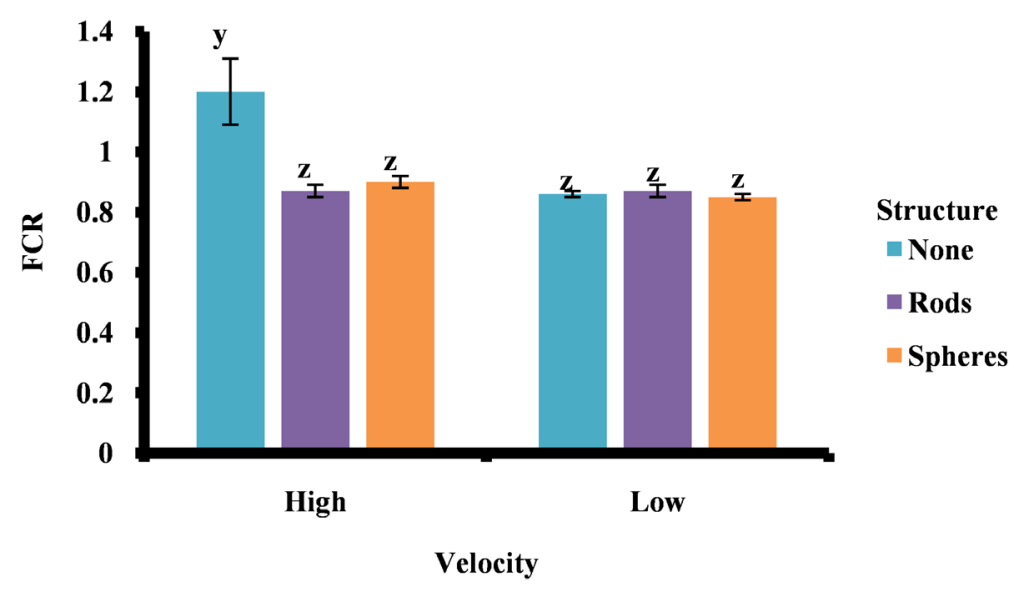

Figure 2. Mean $( \pm$ SE) feed conversion ratio (FCR) of juvenile rainbow trout reared at two different velocities and with three different types of structures for 116 days. Means with different letters are significantly different $(p<0.05, n=4)$.

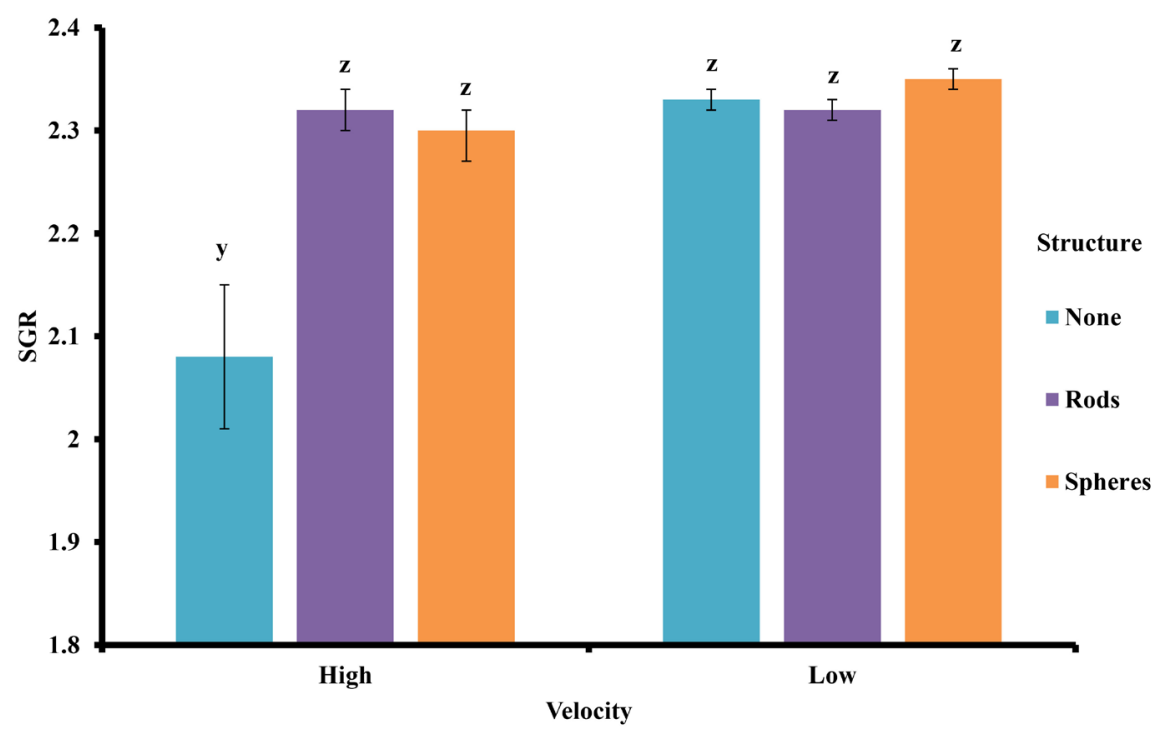

Figure 3. Mean $( \pm \mathrm{SE})$ specific growth rate $(\mathrm{SGR})$ of juvenile rainbow trout reared at two different velocities and with three different types of structures for 116 days. Means with different letters are significantly different $(p<0.05, n=4)$.

\section{Discussion}

The results of this study suggest that vertically-suspended structure may positively impact trout rearing performance by reducing water velocities. Moine et al. [3] and Muggli et al. [4] both showed that vertically-suspended structures significantly alter velocity profiles in circular tanks, particularly by reducing velocities immediately behind the structures. Kientz and Barnes [28] suggested vertically-suspended structure may be providing bioenergetics benefits by creating lower velocity microhabitats. In this study, control fish reared with high velocity were subjected to continual exercise without the refuge provided by suspended structure. In addition, they did not receive the additional feed required to offset the increased energy expenditures from continual exercise [38] 
[39].

It is possible that the higher velocity treatment used in this experiment was too high initially and too difficult for the fish to sustain over 116 days. Exercise at velocities of 1.0 to 2.0 Body Lengths seconds ${ }^{-1}\left(\mathrm{BL} \mathrm{s}^{-1}\right)$ has been reported as optimal fish rearing performance [30] [32] [40] [41] [42] [43] [44]. In contrast, the high velocities used in this study were $4.0 \mathrm{BL} \mathrm{s}^{-1}$ initially, and $1.8 \mathrm{BL} \mathrm{s}^{-1}$ at the end of the experiment. The initial high velocity may have been too great for fish that did not have the lower velocity refuge created by structure [38] [44] [45] [46]. However, because percent mortality was not significantly different among the treatments, the higher velocities were not high enough to be lethal [45].

The feed conversion ratio in all treatments was typical for juvenile rainbow trout reared with exercise [39] [47] [48] or structure [24] [25] [26] [28] [35] [49]. However, feed conversion ratios in this study were lower than those reported in the only other study examining vertically-suspended structure and exercise [23].

Improvements in relative fin length have been reported in fish that are exercised, likely due to decreased agonistic behavior such as fin nipping [30] [31] [32] [39] [42] [50] [51]. Increasing structural complexity with environmental enrichment has also been shown to decrease agonistic behavior [1] [2] [6] [52] [53] [54] [55]. The lack of differences in relative fin length in this study may indicate that even the low velocities were enough to overcome any potential negative effects of fin length from the lack of structure in the control tanks.

It is possible that the long duration of this experiment may have impacted the results. Huysman et al. [35] indicated that growth will slow if carrying capacities are reached in tanks receiving experimental treatments prior to the end of a trial. This allows the slower-growing tanks in other treatments the opportunity to catch-up, thereby masking any potential advantages from selected treatments.

The results of this experiment indicate that water velocity can be increased for prolonged periods with no negative effects on trout rearing performance if vertically-suspended structure is present. Subsequent experimentation using vertically-suspended structure at velocities between $1.0-2.0 \mathrm{BL} \mathrm{s}^{-1}$, particularly if these values were maintained throughout the study by periodic adjustment, would be beneficial. In addition, intermittent exercise, induced by periodic changes in water velocity, in conjunction with vertically-suspended environmental enrichment, may be a productive area for further experimentation.

\section{Acknowledgements}

We thank Kathleen Crank and Miranda Gallagher for their assistance with this experiment.

\section{Conflicts of Interest}

The authors declare no conflicts of interest regarding the publication of this paper. 


\section{References}

[1] Gerber, B., Stamer, A. and Stadtlander, T. (2015) Environmental Enrichment and Its Effects on Welfare in Fish. Review. Research Institute of Organic Agriculture (FiBL), CH-Frick.

[2] Näslund, J. and Johnsson, J.I. (2016) Environmental Enrichment for Fish in Captive Environments: Effects of Physical Structures and Substrates. Fish and Fisheries, 17, 1-30. https://doi.org/10.1111/faf.12088

[3] Moine, J., Barnes, M.E., Kientz, J. and Simpson, G. (2016) Flow Pattern in Circular Rearing Tanks Containing Vertical Structure. Journal of Fisheries and Livestock Production, 4, 4.

[4] Muggli, A.M., Barnes, J.M. and Barnes, M.E. (2019) Vertically-Suspended Environmental Enrichment Alters the Velocity Profiles of Circular Fish Rearing Tanks. World Journal of Engineering and Technology, 7, 208-226. https://doi.org/10.4236/wjet.2019.71014

[5] Berejikian, B.A., Tezak, E.P., Flagg, T.A., LaRae, A.L., Kummerow, E. and Mahnken, C.V.W. (2000) Social Dominance, Growth, and Habitat Use of Age-0 Steelhead (Oncorhynchus mykiss) Grown in Enriched and Conventional Hatchery Rearing Environments. Canadian Journal of Fisheries and Aquatic Sciences, 57, 628-636. https://doi.org/10.1139/f99-288

[6] Maynard, D., Berejikian, B., Flagg, T. and Mahnken, C. (2001) Development of a Natural Rearing System to Improve Supplemental Fish Quality. 1996-1998 Progress Report. Project: 199105500.

[7] Berejikian, B.A. and Tezak, E.P. (2005) Rearing in Enriched Hatchery Tanks Improves Dorsal Fin Quality of Juvenile Steelhead. North American Journal of Aquaculture, 67, 289-293. https://doi.org/10.1577/A05-002.1

[8] Tatara, C.P., Riley, S.C. and Scheurer, J.A. (2008) Environmental Enrichment in Steelhead (Oncorhynchus mykiss) Hatcheries: Field Evaluation of Aggression, Foraging, and Territoriality in Natural and Hatchery Fry. Canadian Journal of Fisheries and Aquatic Sciences, 65, 744-753. https://doi.org/10.1139/f08-004

[9] Bosakowski, T. and Wagner, E.J. (1995) Experimental Use of Cobble Substrates in Concrete Raceways for Improving Fin Condition of Cutthroat (Oncorhynchus clarki) and Rainbow Trout (O. mykiss). Aquaculture, 130, 159-165. https://doi.org/10.1016/0044-8486(94)00223-B

[10] Zydlewski, G.B., Foott, J.S., Nichols, K., Hamelberg, S., Zydlewski, J. and Björnsson, B.T. (2003) Enhanced Smolt Characteristics of Steelhead Trout Exposed to Alternative Hatchery Conditions During the Final Months of Rearing. Aquaculture, 222, 101-117. https://doi.org/10.1016/S0044-8486(03)00105-4

[11] Maynard, D.J., Flagg, T.A., Iwamoto, R.N. and Mahnken, C.V.W. (2004) A Review of Recent Studies Investigating Seminatural Rearing Strategies as a Tool for Increasing Pacific Salmon Postrelease Survival. American Fisheries Society Symposium, 44, 569-580.

[12] Salvanes, A.G.V., Moberg, O., Ebberson, L.O.E., Nilsen, T.O., Jensen, K.H. and Braithwaite, V.A. (2013) Environmental Enrichment Promotes Neural Plasticity and Cognitive Ability in Fish. Proceedings of the Royal Society B, 280, Article ID: 20131331. https://doi.org/10.1098/rspb.2013.1331

[13] Jonsson, B. and Jonsson, N. (2014) Early Environment Influences Later Performance in Fishes. Journal of Fish Biology, 85, 151-188.

https://doi.org/10.1111/jfb.12432 
[14] Krebs, J., Crank, K.M., Krebs, E. and Barnes, M.E. (2017) Use of Bottom Structure and Tank Cover During Rainbow Trout Rearing in Circular Tanks. Journal of Fish Fisheries and Livestock Production, 5, 3. https://doi.org/10.4172/2332-2608.1000247

[15] Brockmark, S., Neregård, L., Bohlin, T., Björnsson, B.T. and Johnsson, J.I. (2007) Effects of Rearing Density and Structural Complexity on the Pre- and Postrelease Performance of Atlantic Salmon. Transactions of the American Fisheries Society, 136, 1453-1462. https://doi.org/10.1577/T06-245.1

[16] Lee, J.S.F. and Berejikian, B.A. (2008) Effects of the Rearing Environment on Average Behaviour and Behavioural Variation in Steelhead. Journal of Fish Biology, 72, 1736-1749. https://doi.org/10.1111/j.1095-8649.2008.01848.x

[17] Strand, D.A., Utne-Palm, A.C., Jakobsen, P.J., Braithwaite, V.A., Jensen, K.H. and Salvanes, A.G.V. (2010) Enrichment Promotes Learning in Fish. Marine Ecology Progress Series, 412, 273-282. https://doi.org/10.3354/meps08682

[18] Näslund, J., Rosengren, M., Del Villar, D., Gansel, L., Norrgård, J.R., Persson, L., Winkowski, J.J. and Kvingedal, E. (2013) Hatchery Tank Enrichment Affects Cortisol Levels and Shelter-Seeking in Atlantic Aalmon (Salmo salar). Canadian Journal of Fisheries and Aquatic Sciences, 70, 585-590.

https://doi.org/10.1139/cjfas-2012-0302

[19] Bergendahl, I.A., Miller, S., Depasquale, C., Giralico, L. and Braithwaite, V.A. (2017) Becoming a Better Swimmer: Structural Complexity Enhances Agility in Captive-Reared Fish. Journal of Biology, 90, 1112-1117. https://doi.org/10.1111/jfb.13232

[20] Self, K.E., Schreck, C.B., Cogliati, K.M., Billman, E.J. and Noakes, D.L.G. (2018) The Effect of Rearing Structures on Behaviour and Movement of Juvenile Steelhead Oncorhynchus mykiss. Journal of Fish Biology, 93, 449-454. https://doi.org/10.1111/jfb.13657

[21] Baynes, S.M. and Howell, B.R. (1993) Observations on the Growth, Survival and Disease Resistance of Juvenile Common Sole, Solea solea (L.), Fed Mytilus edulis L. Aquaculture Research, 24, 95-100. https://doi.org/10.1111/j.1365-2109.1993.tb00831.x

[22] Tuckey, L.M. and Smith, T.I.J. (2001) Effects of Photoperiod and Substrate on Larval Development and Substrate Preference of Kuvenile Southern Flounder, Paralichthys lethostigma. Journal of Applied Aquaculture, 11, 1-20. https://doi.org/10.1300/J028v11n01 02

[23] Kientz, J.L. and Barnes, M.E. (2016) Structural Complexity Improves the Rearing Performance of Rainbow Trout in Circular Tanks. North American Journal of Aquaculture, 78, 203-207. https://doi.org/10.1080/15222055.2016.1159629

[24] Kientz, J.L., Crank, K.M. and Barnes, M.E. (2018) Enrichment of Circular Tanks with Vertically Suspended Strings of Colored Balls Improves Rainbow Trout Rearing Performance. North American Journal of Aquaculture, 80, 162-167. https://doi.org/10.1002/naaq.10017

[25] Krebs, E., Huysman, N., Voorhees, J.M. and Barnes, M.E. (2018) Suspended Arrays Improve Rainbow Trout Growth During Hatchery Rearing in Circular Tanks. International Journal of Aquaculture and Fishery Science, 4, 27-30.

[26] Crank, K.M., Kientz, J.L. and Barnes, M.E. (2019) An Evaluation of Vertically Suspended Environmental Enrichment Structures During Rainbow Trout Rearing. North American Journal of Aquaculture, 81, 94-100. https://doi.org/10.1002/naaq.10064

[27] Rosburg, A.J., Fletcher, B.L., Barnes, M.E., Treft, C.E. and Bursell, B.R. (2019) Ver- 
tically-suspended Environmental Enrichment Structures Improve the Growth of Juvenile Landlocked Fall Chinook Salmon. International Journal of Innovative Studies in Aquatic Biology and Fisheries, 5, 17-24. https://doi.org/10.20431/2454-7670.0501004

[28] White, S.C., Krebs, E., Huysman, N., Voorhees, J.M. and Barnes, M.E. (2019) Use of Suspended Plastic Conduit Arrays During Brown Trout and Rainbow Trout Rearing in Circulars. North American Journal of Aquaculture, 81, 101-106. https://doi.org/10.1002/naaq.10076

[29] Olla, B.L., Davis, M.W. and Ryer, C.H. (1994) Behvaioural Deficits in Hatchery-Reared Fish: Potential Effects on Survival Following Release. Aquaculture and Fisheries Management, 25, 19-34.

[30] Christiansen, J.S. and Jobling, M. (1989) The Behavior and the Relationship Between Food Intake and Growth of Juvenile Arctic Charr, Salvelinus alpinus L., Subjected to Sustained Exercise. Canadian Journal of Zoology, 68, 2185-2191. https://doi.org/10.1139/z90-303

[31] Christiansen, J.S., Ringø, E. and Jobling, M. (1989) Effects of Sustained Exercise on Growth and Body Composition of First-Feeding Fry of Arctic Charr, Salvelinus alpinus (L.). Aquaculture, 79, 329-335. https://doi.org/10.1016/0044-8486(89)90474-2

[32] Davison, W. (1997) The Effects of Exercise Training on Teleost Fish, a Review of Recent Literature. Comparative Biochemistry and Physiology Part A: Physiology, 117, 67-75. https://doi.org/10.1016/S0300-9629(96)00284-8

[33] Brown, C. and Day, R.L. (2002) The Future of Stock Enhancements: Lessons for Hatchery Practice from Conservation Biology. Fish and Fisheries, 3, 79-94. https://doi.org/10.1046/j.1467-2979.2002.00077.x

[34] Gorle, J.M.R., Terjesen, B.F., Mota, V.C. and Summerfelt, S. (2018) Water Velocity in Commercial RAS Culture Tanks for Atlantic Salmon Smolt Production. Aquaculture Engineering, 81, 89-100. https://doi.org/10.1016/j.aquaeng.2018.03.001

[35] Huysman, N., Krebs, E., Voorhees, J.M. and Barnes, M.E. (2019) Use of Large Vertically-Suspended Rod Array in Circular Tanks during Juvenile Rainbow Trout Rearing. International Journal of Marine Biology and Research, 4, 1-5.

[36] Buterbaugh, G.L. and Willoughby, H. (1967) A Feeding Guide for Brook, Brown, and Rainbow Trout. The Progressive Fish-Culturist, 29, 210-215. https://doi.org/10.1577/1548-8640(1967)29[210:AFGFBB]2.0.CO;2

[37] Kindischi, G.A. (1987) Method for Quantifying Degree of Fin Erosion. The Progressive Fish-Culturist, 29, 210-215. https://doi.org/10.1577/1548-8640(1987)49<314:MFQDOF>2.0.CO;2

[38] Parker, T.M. and Barnes, M.E. (2014) Rearing Velocity Impacts on Landlocked Fall Chinook Salmon (Oncorhynchus tsawytscha) Growth, Condition, and Survival. Open Journal of Animal Sciences, 4, 244-252. https://doi.org/10.4236/ojas.2014.45031

[39] Parker, T.M. and Barnes, M.E. (2015) Effects of Different Water Velocities on the Hatchery Rearing Performance and Recovery from Transportation of Rainbow Trout Fed Two Different Rations. Transactions of the American Fisheries Society, 144, 882-890. https://doi.org/10.1080/00028487.2015.1047533

[40] Leon, K.A. (1986) Effect of Exercise on Feed Consumption, Growth, Food Conversion, and Stamina of Brook Trout. The Progressive Fish-Culturist, 48, 43-46. https://doi.org/10.1577/1548-8640(1986)48<43:EOEOFC >2.0.CO;2

[41] Davison, W. (1989) Training and its Effects on Teleost Fish. Comparative Bioche- 
mistry and Physiology Part A: Physiology, 94, 1-10.

https://doi.org/10.1016/0300-9629(89)90775-5

[42] Jobling, M., Baardvik, B.M., Christiansen, J.S. and Jørgensen, E.H. (1993) The Effects of Prolonged Exercise Training on Growth Performance and Production Parameters in Fish. Aquaculture International, 1, 95-111.

https://doi.org/10.1007/BF00692614

[43] Hammer, C. (1995) Fatigue and Exercise Tests with Fish. Comparative Biochemistry and Physiology Part A: Physiology, 122, 1-20. https://doi.org/10.1016/0300-9629(95)00060-K

[44] Liu, G., Wu, Y., Qin, X., Shi, X. and Wang, X. (2018) The Effect of Aerobic Exercise Training on Growth Performance, Innate Immune Response, and Disease Resistance in Juvenile Schizothorax prenanti. Aquaculture, 486, 18-25.

https://doi.org/10.1016/j.aquaculture.2017.12.006

[45] Davison, W. and Goldspink, G. (1977) The Effect of Prolonged Exercise on the Lateral Musculature of the Brown Trout (Salmo trutta). Journal of Experimental Biology, 70, 1-12.

[46] Bagatto, B., Pelster, B. and Burggren, W.W. (2001) Growth and Metabolism of Larval Zebrafish: Effects of Swim Training. Journal of Experimental Biology, 204, 4335-4343.

[47] Voorhees, J.M., Barnes, M.E., Chipps, S.R. and Brown, M.L. (2018) Dietary Bioprocessed Soybean Meal Does Not Affect the Growth of Exercised Juvenile Rainbow Trout (Oncorhynchus mykiss). Journal of Animal Research and Nutrition, 3, 2-6.

[48] Voorhees, J.M., Barnes, M.E., Chipps, S.R. and Brown, M.L. (2019) Effects of Exercise and Bioprocessed Soybean Meal Diets During Rainbow Trout Rearing. The Open Biology Journal, 7, 1-13. https://doi.org/10.2174/1874196701907010001

[49] Huysman, N., Krebs, E., Voorhees, J.M. and Barnes, M.E. (2019) Use of Two Vertically-suspended Environmental Enrichment Arrays during Rainbow Trout Rearing in Circular Tanks. International Journal of Innovative Studies in Aquatic Biology and Fisheries, 5, 25-30. https://doi.org/10.20431/2454-7670.0501005

[50] Jørgensen, E.H. and Jobling, M. (1993) The Effects of Exercise on Growth, Food Utilization and Osmoregulatory Capacity of Juvenile Atlantic Salmon, Salmo salar. Aquaculture, 116, 233-246. https://doi.org/10.1016/0044-8486(93)90011-M

[51] Palstra, A.P. and Planas, J.V. (2011) Fish under Exercise. Fish Physiology and Biochemistry, 37, 259-272. https://doi.org/10.1007/s10695-011-9505-0

[52] Marchetti, M.P. and Nevitt, G.A. (2003) Effects of Hatchery Rearing on Brain Structures of Rainbow Trout, Oncorhynchus mykiss. Environmental Biology of Fishes, 66, 9-14. https://doi.org/10.1023/A:1023269221678

[53] Höjesjö, J., Johnsson, J. and Bohlin, T. (2004) Habitat Complexity Reduces the Growth of Aggressive and Dominant Brown Trout (Salmo trutta) Relative to Subordinates. Behavioral Ecology and Sociobiology, 56, 286-289.

https://doi.org/10.1007/s00265-004-0784-7

[54] Johnsson, J.I., Brockmark, S. and Näslund, J. (2014) Environmental Effects on Behavioural Development Consequences for Fitness of Captive-Reared Fishes in the Wild. Journal of Fish Biology, 85, 1946-1971. https://doi.org/10.1111/jfb.12547

[55] Rosengren, M., Kvingedal, E., Näslund, J., Johnsson, J.I. and Sundell, K. (2017) Born to be Wild: Effects of Rearing Density and Environmental Enrichment on Stress, Welfare, and Smolt Migration in Hatchery-Reared Atlantic Salmon. Canadian Journal of Fisheries and Aquatic Sciences, 74, 396-405. https://doi.org/10.1139/cjfas-2015-0515 